\title{
Histological and histochemical analysis of dry fermented sausage of kulen composition
}

\author{
Vladimir Gajdov ${ }^{*}$, Anita Radovanovićl, Tijana Lužajić Božinovski ${ }^{1}$, Danica Markovićl, Silvana Stajkovićl, \\ Ivan Miloševićl
}

A b s t r a c t: The application of histological methods in meat composition analysis and identification of prohibited tissues and organs added to meat and meat products is still in the research phase, although there have been some promising results. The aim of this work was to assess the possibility of using histological and histochemical methods for analysis of kulen composition. In this research, six samples of kulen were examined, one of which was produced in domestic conditions, while the rest were commercial products sampled from local markets. The samples were carried through classical histological preparation. The obtained slides were stained with haematoxylin/eosin, Masson-Goldner, toluidine blue and periodic acid-Schifflalcian blue. The content of muscle, fat and connective tissue was evaluated using histomorphometric analysis. Histological analysis of kulen composition determined the presence of the following structures: muscle, adipose and connective tissues, blood vessels, glandular epithelium, peripheral nerve, cartilage and plant tissue. The histomorphometric analysis showed that the kulen products contained on average $56 \pm 2.52 \%$ muscle tissue, $7.27 \pm 1.38 \%$ connective tissue and $19.82 \pm 3.24 \%$ adipose tissue. The results show that by applying histological methods it is possible to identify different permitted and prohibited animal tissues in kulen, and hence, it is possible to analyse the composition of kulen. It is also possible to confirm the presence of various plant tissues, but for their precise identification, additional histological methods are needed.

Keywords: fermented sausage, histology, animal tissue, plant tissue, histomorphometry

\section{Introduction}

Kulen is a fermented dry sausage that is produced in Serbia according to a specific recipe and technology, depending on whether it is produced domestically (recognised as domestic kulen) or industrially (when it is recognised as kulen). According to the relevant Serbian regulation (Official Gazette of RS, 50/2019), kulen is defined as a product made from first and second category pork meat, with the addition of solid fat, salt or pickling salt, sugar, additives, ground red pepper, red pepper extract and other spices and starter cultures. The stuffing of kulen is medium to coarsely ground and is filled into natural and artificial large diameter casings.

The meat protein content is at least $22 \%$, while the collagen content in meat proteins is limited to maximum 15\%. Domestic kulen is homemade from first category meat, solid adipose tissue, salt or brine, ground red pepper, red pepper extract and other spices and starter cultures. The stuffing of domestic kulen is medium to coarsely ground and is filled into pig appendix or colon. The content of meat protein in domestic kulen is at least $24 \%$, and the collagen content in meat proteins is up to $10 \%$ (Official $\mathrm{Ga}$ zette of $R S, 50 / 2019$ ). According to the same regulation, first category meat includes skeletal muscles that naturally contain little connective and adipose tissue, or meat in which the portion of connective and adipose tissue is reduced to an appropriate level by processing. Second category meat has a naturally higher proportion of adipose and connective tissue than first category meat, from which connective tissue and larger deposits of adipose tissue have been coarsely separated.

Taking the production method of fermented sausages into account, which involves grinding the raw material, it is possible for various components to be added, be it on purpose or accidentally. Some examples include different types of connective tissue, epithelial and glandular tissue, nerve tissue and different types of plant tissue (Harem and Altun, 2018). The possibility that inadequate carcass processing or inadequate processing of raw input material leads to the appearance of unauthorised components or the presence of permitted components above the limit

${ }^{1}$ University of Belgrade, Faculty of Veterinary Medicine, Department of Histology and Embryology, Belgrade, Republic of Serbia.

*Corresponding author: Vladimir Gajdov, vladimirgajdov91@gmail.com 
values cannot be excluded. Recognising this problem, the Food and Agriculture Organization (FAO) has prepared a set of guidelines for proper processing and preparation of raw materials in order to obtain foods that are in accordance with regulations in terms of composition (FAO, 1991). Raw materials that contain forbidden components are of lower quality because they have lower nutritional values, and on the other hand, can lead to faster spoilage of the finished product.

Microbiological, physicochemical, sensory and chemical analyses are performed when evaluating the quality parameters of kulen. Chemical analyses are used in assessing product quality, among other things. Chemical analysis of kulen composition includes determination of moisture, fat, meat protein, content of collagen in meat protein, ash, chloride, nitrate and nitrite (Official Gazette of RS, 50/2019). Chemical analysis of moisture content shows whether water above the permitted limits has been added to the finished product. Meat protein analysis involves the determination of total nitrogen (SRPS ISO 937:1992), while the collagen content is determined by examining the hydroxyproline content. (SRPS ISO 3496:2002).

In addition to classical chemical methods, numerous additional methods (molecular, chromatographic, electrophoretic, immunochemical) have been developed in order to detect animal and plant tissue in meat products (Kesmen et al., 2007; Rao and Hsieh, 2007). While these methods are very precise and provide valuable information, they can be quite costly and some can be very time consuming for everyday use. Additionally, it is difficult to quantify the presence of plant tissue (Castro et al., 2007). Chemical methods that are used in routine examination of the quality parameters of kulen and other meat products cannot be used to determine the presence of various animal and plant tissues. Additionally, routine methods cannot determine the origin of proteins, i.e., meat proteins cannot be distinguished from other nitrogen-containing compounds, such as plant proteins (Moore et al., 2010).

Numerous researchers have shown that the use of histological methods in combination with routine methods would give more accurate results when evaluating meat quality (Horn and Seidler, 1978; Ugurlu, 1991; Tremlova and Starha, 2003; Mokhtar et al., 2018). These studies have shown that histological methods are one of the most accurate ways to determine various tissues in fermented sausages because they give a comprehensive view of the components that are part of the product. Determination of various tissues and organs using histological methods can be a useful method for detecting counterfeit products (Ince and Ozfiliz, 2018). Histological examination of the composition of fermented sausages allows direct determination of the presence of illicit animal and plant tissues (Ghisleni et al., 2010). Histological methods can also be used to estimate the percentage of muscle and connective tissue in fermented sausages (Koolmees and Bijker, 1985; Ghisleni et al., 2010). Some authors have shown that the application of these methods can relatively easily detect the presence of plant allergens in meat products (Rencova, 2007). Other researchers have applied histological methods to determine the differences between fresh and frozen meat ( $\mathrm{Zhu}$ et al., 2004). One report shows that the best results when analysing fermented sausage or other meat products are obtained by combining chemical and histological methods, which implies that these two methods are complementary (Mokhtar et al., 2018). The aim of this study was to evaluate the usefulness and practicality of histological and histochemical methods to analyse kulen composition.

\section{Materials and Methods}

Six different samples of kulen were studied, one of which was produced in domestic conditions, while the rest were commercial products acquired on the local market. The commercial products were chosen at random from different stores. The samples were marked with unique codes, whereby the one produced in domestic/traditional conditions was labelled DK1, while the commercial products were labelled KK1-KK5. Ten tissue blocks 1 x $0.5 \mathrm{~cm}$ of each product were randomly selected and were fixed in $10 \%$ buffered formaldehyde for 48 hours. The samples were put through standard histological procedure and embedded in paraffin blocks. Six micron-thick sections were obtained from each block. The six sections were stained with haematoxylin/ eosin (MerckMillipore, Darmstadt, Germany), periodic acid- Schiff/alcian blue (MerckMillipore, Darmstadt, Germany), toluidine blue and Masson-Goldner (Masson-Goldner staining kit, MerckMillipore, Darmstadt, Germany).

\section{Histomorphometry}

All histomorphometric measurements were performed on two sections from each examined sample. For each sample, muscle, connective and adipose tissue content was measured. Four micrographs 
were taken from each section at 10x magnification, using a microscope equipped with a digital camera and adequate software (Olympus CX31 with UC50 Soft Imaging Solutions camera and SensEntry 1.13 software, Münster, Germany). All histomorphometric measurements were performed on these micrographs using Photoshop ${ }^{\mathrm{R}} \mathrm{CS} 3$ (Adobe, San Jose, California). In Photoshop ${ }^{\mathrm{R}} \mathrm{CS} 3$ suitable analysis steps were taken for each image captured from tissue sections stained with haematoxylin/eosin. The software enabled the analyst to choose locations of interest in the image, and calculation and export as a .txt file of the measurements for each tissue type. The muscle and connective tissue were individually measured, while adipose tissue content was calculated by subtracting muscle and connective tissue content and artefacts from the total area size of the image analysed. The standard error was calculated for all samples.

\section{Results and Discussion}

Histological analysis of the kulen composition resulted in identification of the following structures: striated muscle tissue, adipose and connective tissue, blood vessels, glandular epithelium, peripheral nerves, cartilage and plant tissues. These structures were found in different amounts in the different kulen samples. The striated muscle tissue was identified by the finding of longitudinally or transversely cut muscle cells, which in some places merged into a homogeneous mass, while in others, muscle cell striation and numerous peripherally located nuclei were observed (Fig. 1a-f). Unilocular adipose tissue was recognised by the finding of adipocytes filled with a large fat droplet bordered by a thin layer of cytoplasm and a cell membrane (Fig. 1 (a, b, d, e, f)).

The presence of connective tissue was confirmed by identifying collagen and elastic fibres, which were particularly highlighted on samples stained with Masson-Goldner because they acquired an intensely green colour. A more detailed analysis revealed that some samples contained loose connective tissue, while other samples had a large amount of dense connective tissue (Fig. 1a). The irregular and wavy fibre distribution suggested it was irregular, dense connective tissue.

The presence of cartilage was confirmed by finding chondrocytes in cartilage lacunae and extracellular matrix characteristic of cartilage (Fig. 1b). In the extracellular matrix, the presence of a darker coloured territorial and lighter interterritorial matrix was confirmed. Careful observation of the interterritorial matrix revealed the presence of connective tissue fibres that suggested that it was elastic cartilage.

Nerve tissue was identified by finding parts of peripheral nerves and observing cross, oblique and longitudinal sections of myelinated nerve fibres (Fig. 1c). All connective tissue components of the peripheral nerve, endoneurium, perineurium and epineurium were observed, especially on the samples stained with Masson-Goldner.

The presence of arteries and veins was determined by minutely analysing the observed blood vessels (Fig. 1d, 1e). The three-layer wall structure of muscular arteries was preserved. Endothelial cells, especially their nuclei, were very prominent in the tunica intima, and the lamina elastica interna was present in some of the samples. The tunica media also retained a recognisable structure dominated by smooth muscle cells and sparse elastic fibres. The tunica adventitia had also been preserved. In one sample, a structure resembling glandular tissue was observed, but for definitive confirmation, additional histological analyses would be needed (Fig. 1f).

The histological analysis showed the presence of several types of plant structures (Fig. 3). One such observed structure resembled the palisade structure of soybean seeds in its appearance and structure (Fig. 3c), although additional analyses are required to definitely determine that it is a soybean seed. In some samples, starch grains were identified, and they occurred in two forms: 1) small grains, irregular in shape with a lighter central zone and darkly coloured edges (Fig. 3d) and 2) oval, larger, homogeneously coloured grains with a characteristic central crack (Fig. 3e). Starch grains were especially prominent on samples stained with the periodic acid-Schiff/alcian blue method, when they had an intensely pink colour.

In all the commercial kulen samples, rod-shaped and coccoid bacteria were observed, with the rod-shaped bacteria being the predominant type (Fig. 3 (a, c, d, e, f)). Bacteria were observed in the form of small clusters located between muscle and adipose tissue. The size of the clusters, as well as the density of bacteria in the clusters, varied between samples. Bacteria were most clearly observed on samples stained with periodic acid-Schiff/alcian blue, where they had a clear blue colour due to the presence of proteoglycans in their cell walls. Histomorphometric analysis revealed that the products contained an average of $54.45 \pm 2.52 \%$ muscle tissue, $7.27 \pm 1.38 \%$ connective tissue and $19.82 \pm 3.24 \%$ adipose tissue. 
Muscle, adipose, connective and plant tissues were found in all samples. Peripheral nerve was found in KK5. Cartilage was identified in KK1, while blood vessels (arteries and veins) were observed in KK2. Starch grains and the structure resembling glandular tissue were observed in KK4. A tabular presentation of the structures found in all examined kulen is given in Table 1.

In all kulen, the most common finding was striated muscle tissue, followed by adipose tissue, which was expected given that these two tissues are the main raw materials for the production
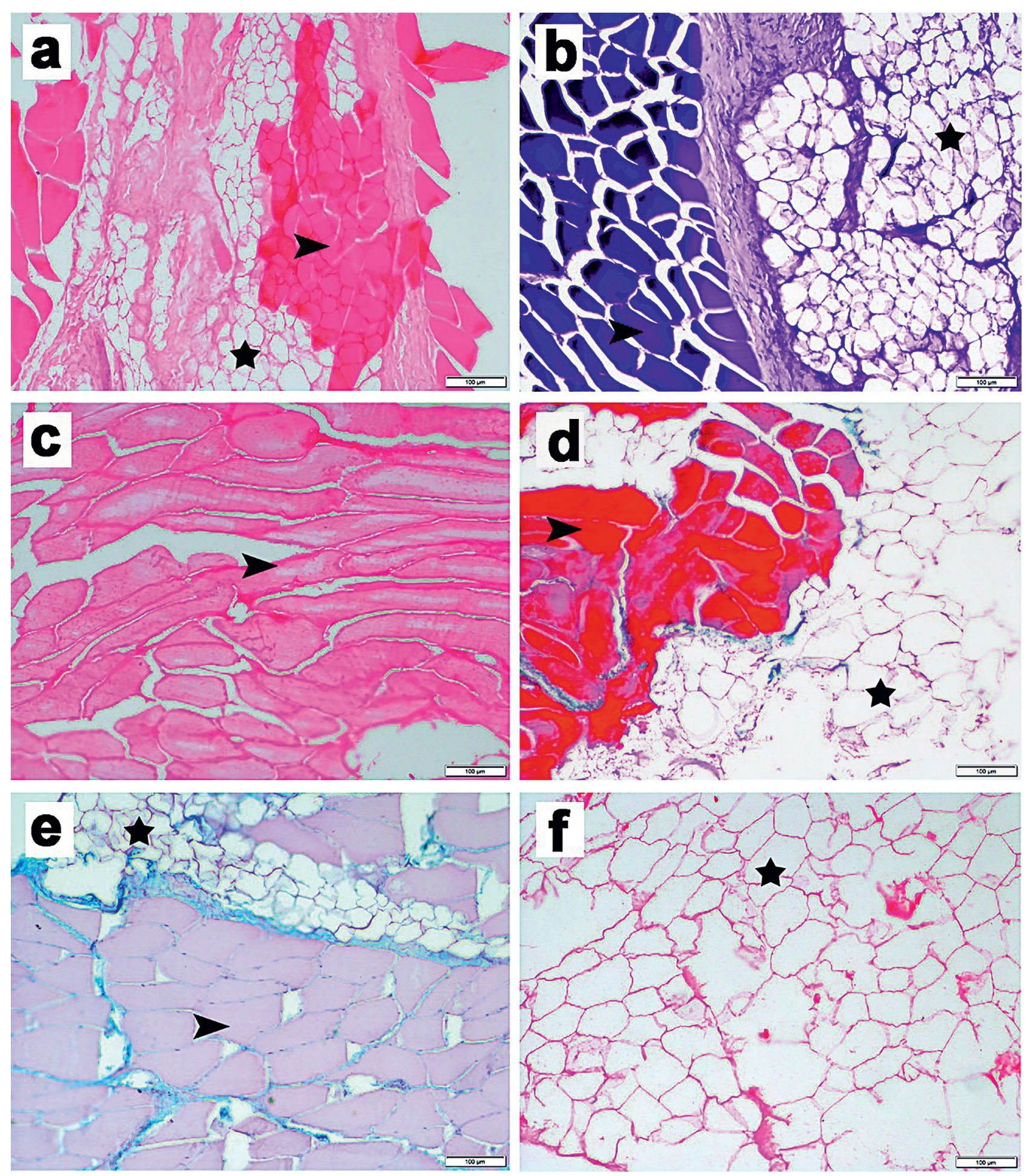

Figure 1. Microphotographs of skeletal muscle tissue (arrowheads) and fat tissue (stars) in commercial and domestic kulen stained with haematoxylin/eosin ( $\mathrm{a}, \mathrm{c}, \mathrm{f})$, toluidine blue (b), Masson-Goldner (d) and periodic acid-Schiff/alcian blue (e). Bars: $100 \mu \mathrm{m}$. 
of kulen. The production of kulen involves grinding and mixing the raw material followed by fermentation. Although these procedures lead to changes in tissue structure, clear visualisation of the muscle and adipose tissue was possible with the histological methods used. Similar observations were made by researchers who performed histological analyses of other types of fermented sausages (Harem and Altun, 2018). Small amounts of connective tissue are expected given that it is not possible to completely
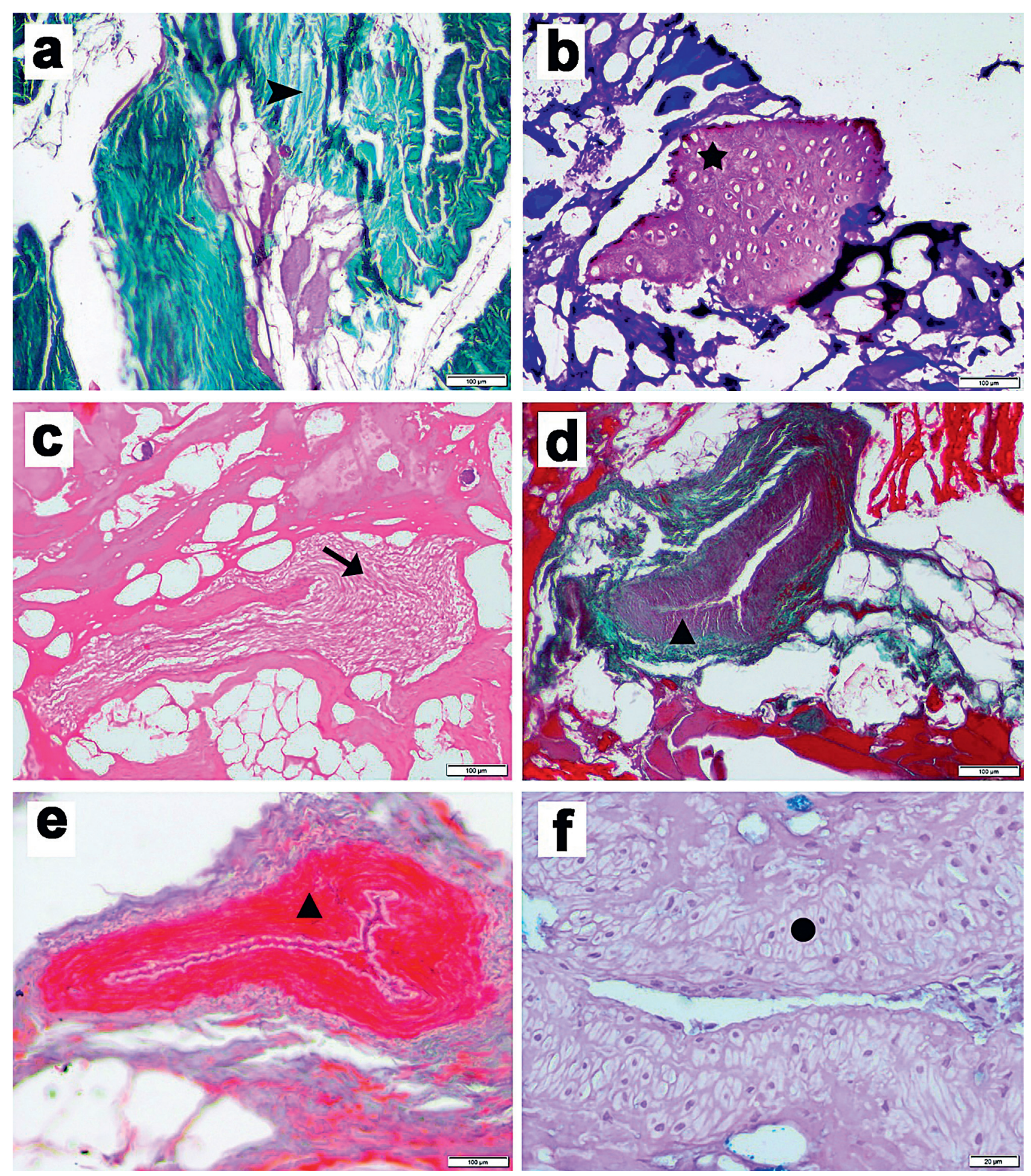

Figure 2. Representative micrographs of domestic and commercial kulen showing: (a) connective tissue marked with arrowhead; (b) cartilage - asterisk; (c) peripheral nerve - arrow; (g, d) arteries of muscle type triangle and; (f) glandular epithelium - circle. Micrographs stained with haematoxylin/eosin (c), toluidine blue

(b), Masson-Goldner (a, d, e), periodic acid-Schiff/alcian blue (f). Bars: $100 \mu \mathrm{m}$ (a, b, c, d, e), $20 \mu \mathrm{m}$ (f). 
separate the connective from the muscle tissue during carcass processing. Connective muscle and adipose tissues were relatively easily discernible and easy to identify.

The findings of the peripheral nerve, blood vessels and cartilage in Kulen are not in accordance with the relevant Serbian regulation (Official Gazette of $R S, 50 / 2019)$. The identification of these tissues was relatively simple, which suggests that histological methods could be used to confirm the presence of illicit tissues in kulen sausages. Many researchers have used histological methods to identify various
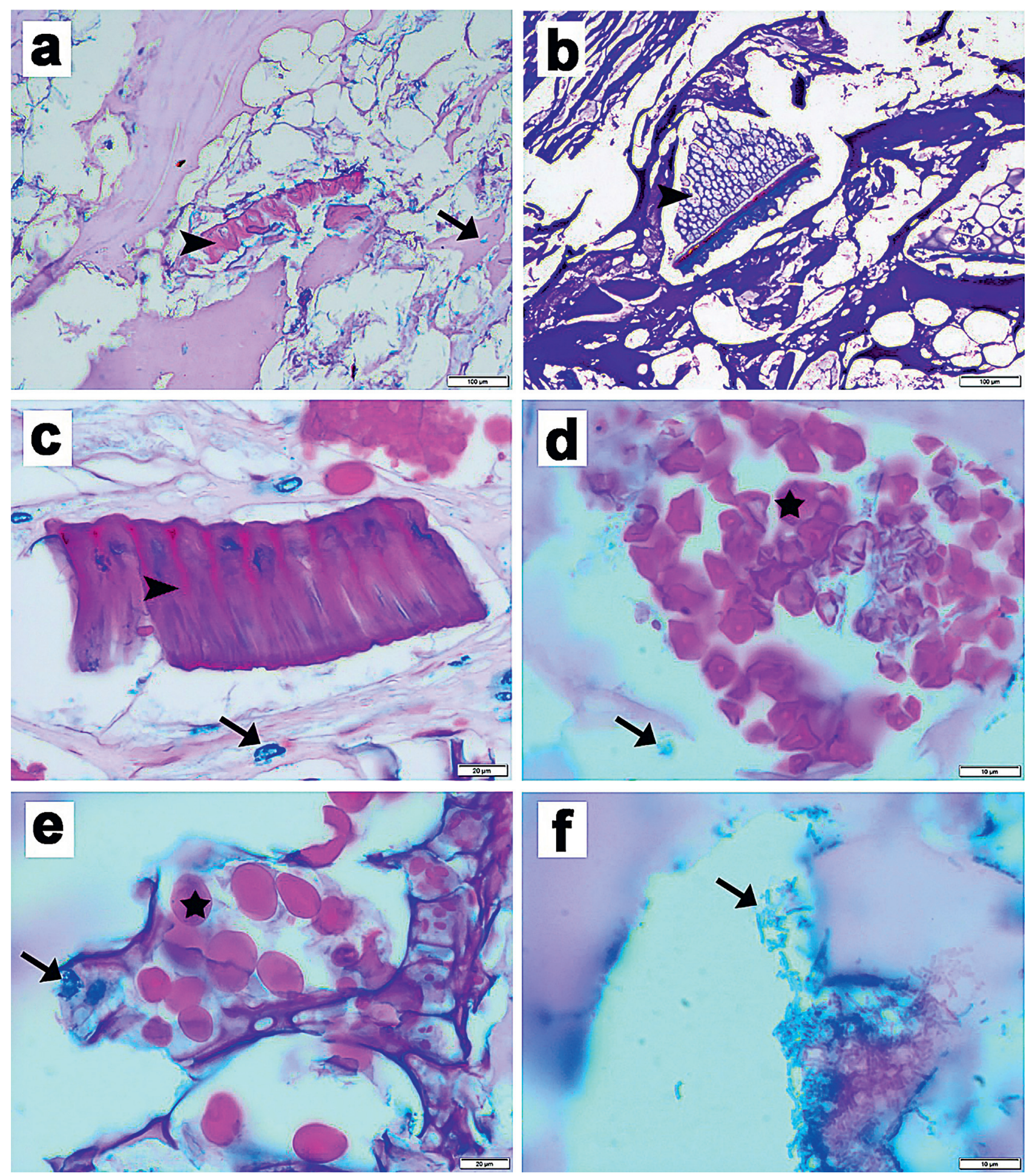

Figure 3. Representative micrographs of domestic and commercial kulen showing different plant tissues marked with arrowheads (a, b, c); starch grains - asterisks (g, d) and; bacteria - arrows (a, v, g, d, f). Micrographs stained with toluidine blue (b) or periodic acid-Schiff/alcian blue (a, c, d, e, f). Bars: $100 \mu \mathrm{m}$ (a, b), $20 \mu \mathrm{m}$ (c, e), $10 \mu \mathrm{m}$ (d, f). 
Table 1. Plant and animal tissues identified in the examined kulen

\begin{tabular}{lcccccc}
\hline \multirow{2}{*}{ Tissue } & \multicolumn{7}{c}{ Kulen } \\
\cline { 2 - 6 } & DK1 & KK1 & KK2 & KK3 & KK4 & KK5 \\
\hline Adipose & + & + & + & + & + & + \\
Muscle & + & + & + & + & + & + \\
Cartilage & - & + & - & - & - & - \\
Glandular & - & - & - & - & $+*$ & - \\
Blood vessels & - & - & + & - & - & - \\
Nerve & - & - & - & - & - & + \\
Plant & + & + & + & + & + & + \\
Connective & + & + & + & + & & + \\
\hline${ }^{+}$indicates a positive finding & & & & &
\end{tabular}

illicit tissues in meat products: cartilage, nerves, blood vessels, lungs, bone, glands, internal organs, tendons and skin (Sezer et al., 2013; Malakauskiene et al., 2016; Migaldi et al., 2016; Harem and Altun, 2018; Moghtaderi et al., 2018; Mokhtar et al., 2018; Abdel-Maguid et al., 2019). In our study, some tissues had an altered structure, so it was not possible to accurately identify them, as was the case with the glandular tissue. Plant tissue was found in all samples, which complies with the relevant Serbian regulation, according to which the use of ground red pepper and other spices in the production of kulen is allowed (Official Gazette of RS, 50/2019). However, a palisade plant tissue structure was found in one kulen sample, and this structure was earlier referred to by others as soybean seed (Mokhtar et al., 2018). The presence of structures characteristic of starch grains in commercial kulen samples could be explained by the addition of various spices or some other plant components. However, additional histological staining is required for accurate identification of the various plant tissues and structures. The presence of rod-shaped and coccoid bacteria can be explained by the fact that starter cultures responsible for the fermentation of the product are used in kulen production.

\section{Conclusion}

Based on the results and their critical consideration, histological methods can be used to identify various permitted and illicit animal tissues in kulen fermented sausages, and the kulen composition can also be analysed. Various plant tissues can be determined, but for their precise identification, additional histological or chemical methods are required. One of the limiting factors of this technique is the lack of precise identification of individual tissues due to structural damage which arises during the production process. 


\title{
Histološka i histohemijska analiza sastava fermentisane kobasice u tipu kulena
}

\author{
Vladimir Gajdov, Anita Radovanović, Tijana Lužajić Božinovski, Danica Marković, Silvana Stajković, \\ Ivan Milošević
}

A p s tr a k t: Primena histoloških metoda u analizi sastava mesa i utvrđivanju prisustva nedozvoljenih tkiva u mesu i proizvodima od mesa je još uvek u fazi istraživanja, iako su postojeći rezultati u ovoj oblasti obećavajući. Cilj našeg istraživanja bio je ispitivanje mogućnosti korišćenja histoloških $i$ histohemijskih metoda u analizi sastava fermentisane kobasice u tipu kulena. U ovom istraživanju ispitano je šest uzoraka kulena, od kojih je jedan proizveden u domaćim uslovima, dok su ostali komercijalni proizvodi poticali iz lokalnih marketa. Uzorci su sprovedeni klasičnom histološkom procedurom. Dobijeni isečci bojeni su metodama: hematoksilin/ eosin,Masson-Goldner, toluidin plavo i perjodna kiselina/Schifflalcijan plavo. Sadržaj mišićnog, masnog $i$ vezivnog tkiva procenjen je primenom histomorfometrijskih analiza. Histološkom analizom sastava kulena utvrđeno je prisustvo sledećih struktura: mišićno, masno i vezivno tkivo, krvni sudovi, epitel žlezdanog tipa, periferni nerv, hrskavica i biljno tkivo. Histomorfometrijska analiza je pokazala

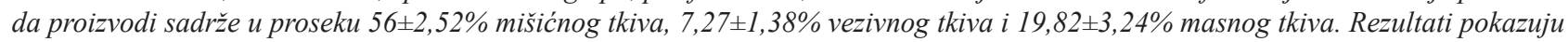
da je primenom histoloških metoda moguće identifikovati različita dozvoljena i nedozvoljena životinjska tkiva u kulenu, pa je samim tim moguće analizirati sastav kulena. Takođe je moguće potvrditi prisustvo različitih biljnih tkiva, ali je za njihovu preciznu identifikaciju neophodno primeniti dodatne metode.

Ključne reči: fermetisane kobasice, histologija, životinjska tkiva, biljna tkiva.

Disclosure statement: No potential conflict of interest was reported by authors.

Acknowledgment: The study was supported by the Ministry of Education, Science and Technological Development of the Republic of Serbia (Contract number 451-03-9/2021-14/200143).

\section{References}

Abdel-Maguid, D. S., Zaki, R. S., Soliman, S. A., Abd-Elhafeez, H. H. \& Mohamed S.A. (2019). Fraudulence risk strategic assessment of processed meat products. Journal of Advanced Veterinary Research, 9 (3), 81-90.

Castro, F., Garcia, M. C., Rodriguez, R., Rodriguez, J. \& Marina, M. L. (2007). Determination of soybean proteins in commercial heat-processed meat products prepared with chicken, beef or complex mixtures of meats from different species. Food Chemistry, 100, 468-476.

Food and Agriculture Organization, (1991). Guidelines for slaughtering, meat cutting and further processing, techniques and hygiene practices in slaughtering and meat handling.

Ghisleni, G., Stella, S., Radaelli, E., Mattiello, S. \& Scanziani, E. (2010). Qualitative evaluation of tortellini meat filling by histology and image analysis. International Journal of Food Science and Technology, 45, 265-270.

Harem, S. I. \& Altun, K. S. (2018). Histological investigation of fermented sausages sold in Sanliurfa province. International Journal of Scientific \& Technology Research 7 (10), 96-99.

Horn, O. \& Seidler, D. (1978). Histometriche bruh wurstunterssuchung vergleich zur chemischen un tersuchung. Die Fleisch, 58 (2), 279-288.

Ince, E. \& Ozfiliz, N. (2018). Detection of adulterations in fermented and heat-treated Turkish type sausages by histological examination. Veteriner Fakültesidergisi, 65 (1), 99-107.

International Organization for Standardization, SRPS ISO 3496:2002, Meat and meat products - Hydroxyproline content determination.

International Organization for Standardization, SRPS ISO 937:1992, Meat and meat products - Nitrogen content determination.

Kesmen, Z., Sahin, F. \& Yetim, H. (2007). PCR assay for the identification of animal species in cooked sausages. Meat Science, 77, 649-653.

Koolmees, P.A. \& Bijker, P. G. H. (1985). Histometric and chemical methods for determining collagen in meats. Veterinary Quarterly, 7 (2), 84-90.

Malakauskiene, S., Alioniene, I., Dziugiene, D., Babrauskiene, V., Riedel, T. A. \& Malakauskas, M. (2016). Histological analysis for a quality evaluation of cured meat sausages. Veterinarijair Zootechnika, 74 (96), 23-26.

Migaldi, M., Rossi, G., Sgambato, A., Farinetti, A. \& Mattioli, V. A. (2016). Histological and immunohistochemical analysis of meat-based food preparations. Progress in $\mathrm{Nu}$ trition, 18 (3), 276-282.

Moghtaderi, A., Raji, A., Khanzadi, S. \& Nabipour, A. (2018). Application of histological method for detection of unauthorized tissues in meat sausage. Veterinary Research Forum, 10 (4) 357-360. 
Mokhtar, M. D., Abd-Elazis, M. D., Youseff, H. \& Taha, A. (2018). Applied histological and chemical analysis for detection of adulteration of minced meat and sausages. Journal of Advanced Microscopy Research, 13, 1-9.

Moore, J. C., DeVries, J., Lipp, M., Griffiths, J.C. \& Abernethy, D. R. (2010). Total protein methods and their potential utility to reduce the risk of food protein adulteration. Comprehensive Reviews in Food Science and Food Safety, 3, 331-357.

Pospiech, M., Tremlová, B., Renčová, E. \& Randulová, Z. (2009). Immunohistochemical detection of soya protein - Optimisation and verification of the method. Czech Journal of Food Sciences, 27 (1), 11-19.

Serbia. (2019). Regulation on meat quality, semi-finished meat products and meat products. Official Gazette of the Republic of Serbia, 50.

Rao, Q. \& Hsieh, Y. H. P. (2007). Evaluation of a commercial lateral flow feed test for rapid detection of beef and

Paper received: October $11^{\text {th }} 2021$.

Paper corrected: November $10^{\text {th }} 2021$.

Paper accepted: November $5^{\text {th }} 2021$. sheep content in raw and cooked meats. Meat Science, 76, 489-494.

Sezer, C., Aksoy, A., Celebi, O., Deprem, T., Ogun, M., Oral, B. N., Vatansever, L. \& Guven, A. (2013). Evaluation of the quality characteristics of fermented sausages and sausage-like products sold in Kars. Eurasian Journal of Veterinary Sciences, 143-149.

Tremlova, B. \& Starha, P. (2013). Histometric Evaluation of Meat Products - Determination of Area and Comparison of Results Obtained by Histology and Chemistry. Czech Journal of Food Science, 21 (3), 101-106.

Ugurlu, S. (1991). Turkiye'de uretilen sucuk ve salamlarin histolojic ve histometrik yontemlerle kalite kontrolu. Bursa Uluslararasi Gida Seтроzуuтu, 1-3.

Zhu, S., Bajl, A. L., Ramaswamy, H. S. \& Chapleau, N. (2004). Characterization of ice crystals in pork muscle formed by pressure - shift freezing as compared with classical freezing methods. Food Engineering and Physical Properties, 69 (4), 191-197. 